\title{
Yellow sweet potato flour: use in sweet bread processing to increase $\beta$-carotene content and improve quality
}

\author{
AMANDA C. NOGUEIRA ${ }^{1}$, GEORGIA A.R. SEHN ${ }^{1,2}$, ANA PAULA REBELLATO ${ }^{3}$, JANCLEI P. COUTINHO ${ }^{3,4}$, \\ HELENA T. GODOY ${ }^{3}$, YOON K. CHANG ${ }^{1}$, CAROLINE J. STEEL ${ }^{1}$ and MARIA TERESA P.S. CLERICI ${ }^{1}$ \\ ${ }^{1}$ Departamento de Tecnologia de Alimentos, Faculdade de Engenharia de Alimentos, Universidade Estadual de \\ Campinas, Rua Monteiro Lobato, 80, Cidade Universitária, Barão Geraldo, 13083-862 Campinas, SP, Brazil \\ ${ }^{2}$ Departamento de Engenharia de Alimentos e Engenharia Química, Universidade Estadual \\ de Santa Catarina, 160, Km 68, 89870-000 Pinhalzinho, SC, Brazil \\ ${ }^{3}$ Departamento de Ciência de Alimentos, Faculdade de Engenharia de Alimentos, Universidade Estadual de \\ Campinas, Rua Monteiro Lobato, 80, Cidade Universitária, Barão Geraldo, 13083-862 Campinas, SP, Brazil \\ ${ }^{4}$ Departamento de Ciências Exatas e Tecnológicas, Campus Soane Nazaré de Andrade, Universidade \\ Estadual de Santa Cruz, Rodovia Jorge Amado, Km 16, Salobrinho, 45662-900 Ilhéus, BA, Brazil
}

Manuscript received on November 8, 2015; accepted for publication on April 21, 2016

\begin{abstract}
Yellow sweet potato is mostly produced by small farmers, and may be a source of energy and carotenoids in the human diet, but it is a highly perishable crop. To increase its industrial application, yellow sweet potato flour has been produced for use in bakery products. This study aimed to evaluate the technological quality and the carotenoids content in sweet breads produced with the replacement of wheat flour by $0,3,6$, and $9 \%$ yellow sweet potato flour. Breads were characterized by technological parameters and $\beta$-carotene levels during nine days of storage. Tukey's test $(p<0.05)$ was used for comparison between means. The increase in yellow sweet potato flour concentrations in bread led to a decrease of specific volume and firmness, and an increase in water activity, moisture, orange coloring, and carotenoids. During storage, the most significant changes were observed after the fifth day, with a decrease in intensity of the orange color. The $\beta$-carotene content was 0.1656 to $0.4715 \mu \mathrm{g} / \mathrm{g}$ in breads with yellow sweet potato flour. This work showed a novel use of yellow sweet potato in breads, which brings benefits to consumers' health and for the agricultural business.
\end{abstract}

Key words: baking, carotenoids, tubers, healthiness, agribusiness.

\section{INTRODUCTION}

Sweet potato (Ipomoea batatas) is a tuber of tropical and subtropical climate with distinct characteristics, such as easy cultivation by both large and small farmers, great adaptability and

Correspondence to: Maria Teresa Pedrosa Silva Clerici

E-mail: mclerici@unicamp.br resistance, and low production cost, which makes it important for the agribusiness in developing countries. It varies widely in shape, size, weight, and color, according to type, cultivar and environment, which can also cause differences in the content of carotenoids, as the sweet potato is considered a source $\beta$-carotene (provitamin A), as well as of 
antioxidants, carbohydrates, fibers, minerals and vitamins (Rodriguez-Amaya and Kimura 2004).

The difference in carotenoids can be observed in several studies. Beauregard cultivar, characterized by its pulp of intense orange color, has an average of $115 \mathrm{ug} / \mathrm{g}$ of $\beta$-carotene in the fresh root (Rodriguez-Amaya et al. 2011). Alves et al. (2012) found, for this cultivar, $185 \mu \mathrm{g} / \mathrm{g}$ of total carotenoids. Donado-Pestana et al. (2012), in several cultivars of orange-fleshed sweet potato, observed high levels of carotenoids in raw roots, predominantly $\beta$-carotene (791-1285 $\mu \mathrm{g} / \mathrm{g}$ in dry matter). According to Takahata et al. (1993), the content of carotenoids in sweet potatoes of orange or yellowish-white pulp can range from $<0.05$ to $265 \mu \mathrm{g} / \mathrm{g}$.

During processing, carotenoids in food are unstable to the action of heat, light, and oxygen, and may suffer total or partial isomerization and degrade depending on time and temperature conditions (Fonseca et al. 2008). Therefore, these conditions should be taken into account when processing yellow sweet potatoes, once their high perishability during storage can be prevented by dehydration processes to extend shelf life (Rodriguez-Amaya et al. 2011, Alves et al. 2012).

In Brazil, breads are mainly made from flour obtained from Triticum aestivum L., classified as bread flour (Brasil 2001). However, in some countries, durum wheat (Triticum turgidum L. ssp. turgidum var. durum) is also used for breads, which by having carotenoids, naturally produces a yellowish crumb color. Durum wheat is imported for pasta production in Brazil, because the country is not self-sufficient in the production of wheat for bread and pasta (ABITRIGO 2016). So, the employment of sweet potato can be a new alternative to supply carotenoids to Brazilian breads, increasing technological and nutritional quality.

Bakery has been a viable sector for incorporation of healthy nutrients, due to its great industrial growth and large capacity to insert regional products, such as artisanal bread with yam, carrot and other vegetables, thus contributing to the agribusiness. In addition, the use of yellow sweet potato in bakery, pasta, and foods served at school (Rodriguez-Amaya et al. 2011) can bring health benefits due to its bioactive compounds.

This study aimed to investigate the technological characteristics and $\beta$-carotene content of sweet bread produced with lyophilized yellow sweet potato flour.

\section{MATERIALS AND METHODS}

\section{MATERIALS}

Wheat flour (WF) obtained from Triticum aestivum L. appropriate for bread production (Moinho Paulista S/A, Santos, Brazil) and sweet potato of yellow pulp were purchased in the local market (Campinas, Brazil).

For the bread formulation, the following ingredients were used: water, palm fat (Cargill, Mairinque, Brazil), instant dry yeast for sweet dough (Fleischmann, AB Brazil, Pederneiras, Brazil), sodium chloride and sucrose purchased in the local market, and the additives calcium propionate (Fleischmann, AB Brazil, Pederneiras, Brazil), diacetyl tartaric acid esters of mono and diglycerides (DATEM) (Granotec, Curitiba, Brazil), and Grindamyl ${ }^{\circledR}$ A 5000 B fungal $\alpha$-amylase (Danisco/DuPont, Cotia, Brazil).

\section{METHODS}

\section{Production of yellow sweet potato flour (SPF)}

The sweet potatoes were previously selected, sanitized, peeled, cut into $3 \mathrm{~cm} \times 1 \mathrm{~cm}$ pieces, and subjected to blanching with hot water until inactivation of peroxidase $\left(100^{\circ} \mathrm{C} / 5 \mathrm{~min}\right)$ (guaiacolnegative test). After draining the water, the potatoes were packed in low density polyethylene (LDPE) bags, white pigmented with $1.5 \%$ titanium dioxide 
(Plastunion Indústria de Plásticos Ltda., Caieiras, Brazil), vacuum-sealed (700 $\mathrm{mmHg})$ using a packing machine (200B, Selovac, São Paulo, Brazil), and frozen $\left(-40^{\circ} \mathrm{C}\right)$. Then, the samples were freeze-dried (Liotop LP820, Liobras Comércio e Serviço de Liofilizadores, São Carlos, Brazil) for 24 hours, ground using a blender (OBL10/2, Oxy, Santana de Parnaíba, Brazil), and passed through a 32 mesh sieve, thus obtaining the SPF, which was packed in low density polyethylene plastic (LDPE) bags and stored at $10^{\circ} \mathrm{C}$ until bread making (less than 15 days).

\section{Characterization of the raw materials}

Moisture, crude protein, ether extract, and ash were determined in the SPF and WF, according to AACC International Approved Methods 4415.02, 46-13.01, 30-25.01 and 08-01.01 (AACC 2010), respectively. Total carbohydrate content was calculated by difference $=[100-($ moisture + protein + ether extract + ash)].

Color was determined according to the $L^{*}, a^{*}$ and $b^{*}$ parameters, using a MiniScan spectrophotometer (Hunterlab, Reston, United States), following the CIELab system (Francis and Clydesdale 1975).

Reducing sugars were determined in the SPF according to the method of Lane and Enyon, method number 176/IV (Instituto Adolfo Lutz 2008), and the $\beta$-carotene content was determined as described in the statistical analysis section.

\section{Rheological characterization of WF and SPF blends}

To produce the blends, WF was mixed with SPF at concentrations of $0 \%(\mathrm{~F} 0), 3 \%(\mathrm{~F} 1), 6 \%(\mathrm{~F} 2), 9 \%$ (F3) and $12 \%$ (F4) using a V-type mixer (model TE 200/20, Tecnal, Piracicaba, Brazil) for 15 minutes. The maximum SPF concentration in the blends was determined according to the following methods:
- AACC International Approved Method 5421.02 (AACC 2010) using a farinograph, model 810130 (Brabender, Duisburg, Germany).

- AACC International Approved Method 5230.02 (AACC 2010) using an alveograph, model MA 95 (Chopin, Villeneuve-laGarenne, France).

\section{Bread formulation}

The bread formulations B0, B1, B2, and B3 were prepared using the WF and SPF blends, as shown in Table I. Sucrose content was calculated according to the reducing sugars in the SPF for each replacement level.

\section{Manufacturing process}

The modified straight dough method was used for the preparation of the breads. The ingredients were mixed in a mixer, model HAE15 (Hyppolito, Ferraz de Vasconcelos, Brazil), at low speed (90 rpm) for 5 minutes, and then at high speed (210 rpm) until complete development of the gluten network $(3.0 \pm 0.3 \mathrm{~min})$. At the end of the mixing stage, the dough temperature was $24 \pm 1.0^{\circ} \mathrm{C}$. The dough was divided into portions of $50 \pm 1 \mathrm{~g}$, rounded, placed in baking pans previously greased with palm oil, and left to rest for $15 \mathrm{~min}$. Then, the portions were proofed in a proofing chamber, model 20B (Klimaquip, Pouso Alegre, Brazil), with controlled temperature $\left(30 \pm 3^{\circ} \mathrm{C}\right)$ and relative humidity $(80 \pm 5 \%)$ for approximately $100 \mathrm{~min}$, to reach their maximum volume without losing resistance when touched (subjective assessment) and baked for 25 minutes in an hearth oven, model HF4B (Haas, Curitiba, Brazil), at $170 \pm 5^{\circ} \mathrm{C}$. After cooling for 2 hours, breads were packed in LDPE bags and stored at room temperature $\left(25^{\circ} \mathrm{C}\right)$ in the presence of light. 
TABLE I

Formulations for the breads with different blends of wheat flour and yellow sweet potato flour.

\begin{tabular}{ccccc}
\hline Ingredients & B0 & B1 & B2 & B3 \\
\hline $\begin{array}{c}\text { Refined wheat } \\
\text { flour }\end{array}$ & 100 & 97 & 94 & 91 \\
$\begin{array}{c}\text { Yellow sweet } \\
\text { potato flour }\end{array}$ & 0 & 3 & 6 & 9 \\
\hline $\begin{array}{c}\text { Water * } \\
\text { Sucrose* }\end{array}$ & 53 & 57 & 60 & 65 \\
$\begin{array}{c}\text { Palm fat* } \\
\text { Salt* }\end{array}$ & 5 & 5 & 5 & 5.45 \\
$\begin{array}{c}\text { Instant dry } \\
\text { yeast for }\end{array}$ & 1.5 & 1.8 & 1.8 & 1.8 \\
sweet dough* \\
$\begin{array}{c}\text { Calcium } \\
\text { propionate* } \\
\text { DATEM* }\end{array}$ & 0.2 & 0.2 & 0.2 & 0.2 \\
$\begin{array}{c}\text { Fungal } \\
\alpha \text {-amylase* }\end{array}$ & 0.0025 & 0.0025 & 0.0025 & 0.0025 \\
\hline
\end{tabular}

*\% flour basis (percent on a 100 basis of refined wheat flour or blend with sweet potato flour); DATEM = diacetyl tartaric acid esters of mono and diglycerides. B $0=0 \%$ of yellow sweet potato flour.

\section{Technological parameters of the breads during} storage

The following methods were used to evaluate the breads after 1,5 , and 9 days of storage:

- Bread: specific volume, AACC International Approved Method 10-05.01 (AACC 2010) on day 1.

- Crumb (considered as the inside portion eliminating $1 \mathrm{~cm}$ margin from the edges) (from day 1 to day 9 of storage): moisture determined by AACC International Approved Method 44-15.02 (AACC 2010); water activity measured in an AquaLab digital apparatus (model CX-2, Decagon, Pullman, United States); color coordinates $L^{*}, a^{*}$ and $b^{*}$ and $\Delta \mathrm{E}$ measured in a MiniScan spectrophotometer (Hunterlab, Reston, United States), according to the CIELab system (Minolta 1993); and firmness measured by AACC method 7409.01 (AACC 2010), using a TA-XT2 texture analyzer, with a $50 \mathrm{~kg}$ load cell (Stable Micro Systems, Surrey, England) and a $\mathrm{P} / 36$ cylindrical aluminum probe. The operation parameters were pre-test speed $=1.0 \mathrm{~mm} / \mathrm{s}$, test speed $=1.7 \mathrm{~mm} / \mathrm{s}$, posttest speed $=10.0 \mathrm{~mm} / \mathrm{s}$, distance $=40 \%$. A 25 $\mathrm{mm}$ thick slice was placed horizontally on the platform and then compressed with a $\mathrm{P} / 36$ probe. Eight replicates were performed for each test.

\section{$\beta$-carotene content in breads}

The chromatographic analysis was performed by UPLC (ultra-performance liquid chromatography) (Acquity UPLC H-Class, Waters), equipped with a quaternary solvent delivery system, auto-sampler with temperature set at $20^{\circ} \mathrm{C}$, column heater set at $40^{\circ} \mathrm{C}$, and diode array detector operating at 450 $\mathrm{nm}$. The separation was performed on a Hypersil Gold C18 column ( $1.9 \mu \mathrm{m}, 3 \times 100$ mm I.D., Thermo Scientific) and the mobile phase was composed of water and acetonitrile $(\mathrm{ACN})$, starting the gradient at $70 \% \mathrm{ACN}$ at a flow rate of $0.55 \mathrm{~mL} \cdot \mathrm{min}^{-1}$, increasing to $100 \% \mathrm{ACN}$ in $0.5 \mathrm{~min}$ at a flow rate of $0.70 \mathrm{~mL} \cdot \mathrm{min}^{-1}$. After 6 minutes, the mobile phase composition was modified back to the initial condition, remaining this way for one more minute.

The $\beta$-carotene peak was identified by comparing the retention time to the standard analyzed under similar conditions, using the absorption spectrum obtained with the diode array detector and co-chromatography. The $\beta$-carotene standard was isolated from carrot as described by Rodriguez-Amaya (2001), and quantified by a 7-point external calibration curve. The chromatographic method was validated for the samples according to Danzer and Currie (1998).

All validation parameters were considered suitable for the chromatographic method proposed. The linear range was determined through an analytical curve constructed with seven equidistant points, in triplicate, with concentrations from 
$0.346 \mu \mathrm{g} \cdot \mathrm{mL}^{-1}$ to $3.46 \mu \mathrm{g} \cdot \mathrm{mL}^{-1}$. The regression coefficient was 0.999 , which was subjected to analysis of variance $(p<0.05)$, with $\mathrm{F}$ value of $21515.87(p=0.0000)$ for the regression model and $1.42(p=0.2767)$ for lack of fit, thus the model is able to predict changes. The detection and quantification limits were 0.028 and $0.056 \mu \mathrm{g} \cdot \mathrm{mL}^{-1}$, respectively. For the parameter repeatability, the relative standard deviation was lower than $0.22 \%$ and $4.72 \%$ for the retention time and the signal of $\beta$-carotene, respectively. For the intermediate precision, a relative standard deviation $>0.30 \%$ for the retention time and $5.09 \%$ for the signal area of $\beta$-carotene were not observed.

\section{Statistical analysis}

The results were evaluated by calculating means, standard deviations, analysis of variance (ANOVA) and, if significant, mean comparisons using Tukey's test $(p \leq 0.05)$. Statistical analysis was performed using the software Statistica 7.0 (Statsoft, Tulsa, USA).

\section{RESULTS AND DISCUSSION}

\section{CHARACTERIZATION OF THE RAW MATERIALS}

The physicochemical characterization of WF and SPF is presented in Table II. The WF had moisture and ash contents according to the Brazilian legislation (Brasil 2005a, b). Protein content is one of the main criteria in determining the end-use quality of the flour, and may be between 11.5 to $14.5 \%$ for pan bread (Schiller 1984), thus, the WF of the present study is suitable for production of sweet breads.

The color of the WF comes mainly from its carotenoids, proteins, fibers and impurities from milling operations. In general, wheat flour for bakery should be white or slightly yellowish without black spots (bran residues). In this study, the color parameters of the WF (Table II) are according to these characteristics.

An orange color was observed for the dehydrated yellow SPF, probably due to the presence of carotenoids, anthocyanins and phenolic compounds, which can vary according to the cultivars. Ali et al. (2012) found $L^{*}$ values ranging from 72.2 to $79.7, a^{*}$ values from -1.8 to 13 and $b^{*}$ values from 13.1 to 30.2 for this tuber. Amenya and Wilson (1997) have reported that the intensity of the orange color is an indicator of the concentration of $\beta$-carotene, which is the main carotenoid with pro-vitamin A activity, thus color measurements may be used to rapidly assess the contents of this compound. The authors have also found a positive correlation between the color parameter $b *$ (yellow) and $\beta$-carotene levels. Pasqualone et al. (2004) also observed this positive correlation between $b^{*}$ and carotenoids in durum wheat semolina. Different to Takahata et al. (1993), who reported that the coordinate $a^{*}$ (red) may be the most appropriate parameter for estimating the $\beta$-carotene contents in sweet potatoes.

The $\beta$-carotene content in the SPF was 6.03 $\pm 0.39 \mu \mathrm{g} / \mathrm{g}$, which is within the range found by

TABLE II

Characterization of refined wheat flour and yellow sweet potato flour ${ }^{\text {a }}$.

\begin{tabular}{|c|c|c|c|}
\hline \multicolumn{2}{|l|}{ Parameters } & WF & SPF \\
\hline \multicolumn{2}{|c|}{ Moisture (\%) } & $11.02 \pm 0.15$ & $8.72 \pm 0.07$ \\
\hline \multicolumn{2}{|c|}{ Protein $(\%)$} & $11.10 \pm 0.07$ & $2.90 \pm 0.04$ \\
\hline \multicolumn{2}{|c|}{ Ether extract (\%) } & $0.87 \pm 0.04$ & $0.32 \pm 0.02$ \\
\hline \multicolumn{2}{|c|}{ Ash (\%) } & $0.58 \pm 0.02$ & $1.64 \pm 0.06$ \\
\hline \multicolumn{2}{|c|}{$\begin{array}{c}\text { Carbohydrates by } \\
\text { difference }(\%)\end{array}$} & 76.43 & 86.42 \\
\hline \multicolumn{2}{|c|}{ Reducing sugars $(\%)^{\mathrm{b}}$} & na & $6.23 \pm 0.56$ \\
\hline \multirow{3}{*}{$\begin{array}{c}\text { Color } \\
\text { parameters }\end{array}$} & $L^{*}$ & $97.00 \pm 0.04$ & $87.22 \pm 0.22$ \\
\hline & $a^{*}$ & $0.71 \pm 0.02$ & $2.08 \pm 0.02$ \\
\hline & $b^{*}$ & $10.36 \pm 0.19$ & $29.34 \pm 0.29$ \\
\hline \multicolumn{2}{|c|}{$\beta$-carotene $(\mu \mathrm{g} / \mathrm{g})^{\mathrm{b}}$} & nd & $6.03 \pm 0.39$ \\
\hline
\end{tabular}

${ }^{\mathrm{a}}$ Mean \pm standard deviation; $\mathrm{WF}=$ refined wheat flour; $\mathrm{SPF}=$ yellow sweet potato flour; na = not analyzed; nd = below the limit of detection. ${ }^{\mathrm{b}}$ The values are in dry matter. 
TABLE III

Farinograph and alveograph rheological parameters of blends of refined wheat flour and yellow sweet potato flour*.

\begin{tabular}{|c|c|c|c|c|c|}
\hline Formulations & Fo & F1 & F2 & F3 & F4 \\
\hline WF $(\%)$ & 100 & 97 & 94 & 91 & 88 \\
\hline SPF (\%) & 0 & 3 & 6 & 9 & 12 \\
\hline \multicolumn{6}{|l|}{ Farinograph } \\
\hline WA $(\%)$ & $56.13 \pm 0.23^{\mathrm{e}}$ & $58.67 \pm 0.31^{\mathrm{d}}$ & $61.10 \pm 0.10^{\mathrm{c}}$ & $63.77 \pm 0.49^{\mathrm{b}}$ & $66.15 \pm 0.15^{\mathrm{a}}$ \\
\hline DT (min) & $13.47 \pm 0.76^{\mathrm{a}}$ & $10.70 \pm 0.60^{b}$ & $8.17 \pm 0.21^{\mathrm{c}}$ & $6.87 \pm 0.55^{\mathrm{cd}}$ & $5.60 \pm 0.80^{\mathrm{d}}$ \\
\hline $\mathrm{S}$ (min) & $18.93 \pm 0.15^{\mathrm{a}}$ & $15.60 \pm 0.61^{\mathrm{b}}$ & $11.30 \pm 0.26^{\mathrm{c}}$ & $8.90 \pm 0.36^{\mathrm{d}}$ & $7.60 \pm 0.10^{\mathrm{e}}$ \\
\hline MTI (BU) & $16.00 \pm 1.73^{\mathrm{e}}$ & $33.33 \pm 5.77^{d}$ & $59.33 \pm 1.15^{\mathrm{c}}$ & $76.67 \pm 5.77^{\mathrm{b}}$ & $80.00 \pm 10.00^{a}$ \\
\hline \multicolumn{6}{|l|}{ Alveograph } \\
\hline $\mathrm{P}(\mathrm{mm})$ & $87.63 \pm 5.46^{\mathrm{c}}$ & $98.57 \pm 2.37^{\mathrm{bc}}$ & $121.73 \pm 20.50^{\mathrm{ab}}$ & $132.90 \pm 4.47^{\mathrm{a}}$ & nd \\
\hline $\mathrm{L}(\mathrm{mm})$ & $71.33 \pm 2.31^{\mathrm{a}}$ & $61.00 \pm 7.94^{\mathrm{a}}$ & $48.00 \pm 2.00^{\mathrm{b}}$ & $47.67 \pm 4.73^{b}$ & nd \\
\hline $\mathrm{P} / \mathrm{L}$ & $1.22 \pm 0.07^{\mathrm{b}}$ & $1.63 \pm 0.20^{\mathrm{b}}$ & $2.55 \pm 0.53^{\mathrm{a}}$ & $2.81 \pm 0.32^{\mathrm{a}}$ & nd \\
\hline $\mathrm{W}\left(10^{-4} \mathrm{~J}\right)$ & $249.26 \pm 23.544^{\mathrm{ns}}$ & $241.17 \pm 23.94^{\mathrm{ns}}$ & $232.87 \pm 35.16^{\mathrm{ns}}$ & $264.67 \pm 17.0^{\mathrm{ns}}$ & nd \\
\hline
\end{tabular}

*Mean \pm standard deviation; WF $=$ refined wheat flour; SPF $=$ yellow sweet potato flour; F0 = 0\% of SPF; F1 = 3\% of SPF; F2 $=6 \%$ of SPF; F3 $=9 \%$ of SPF; F $4=12 \%$ of SPF; WA = water absorption; DT = development time; S = stability; MTI = mixture tolerance index; $\mathrm{BU}=$ Brabender units; $\mathrm{P}=$ maximum pressure required; $\mathrm{L}=$ extensibility of the dough; $\mathrm{W}=$ baking strength of the dough. Means with the different letters in the same line differ statistically $(p \leq 0.05)$ by Tukey test; $\mathrm{ns}=$ not significant; $\mathrm{nd}=$ below the limit of detection.

Fonseca et al. (2008), who found 101 and 4.38 $\mu \mathrm{g} / \mathrm{g} \beta$-carotene in orange and cream-colored sweet potatoes, respectively, and $293.97 \mu \mathrm{g} / \mathrm{g}$ and 15.87 $\mu \mathrm{g} / \mathrm{g}$ total carotenoids in the respective flours.

\section{RHEOLOGICAL PROPERTIES OF WF AND WF AND SPF BLENDS}

As can be seen in Table III, the samples F0 to F3 presented suitable farinograph and alveograph results for bread production.

According to Pomeranz (1988), the flour used to produce pan breads should have the following farinograph characteristics: medium to high water absorption (WA), dough development time (DT) of 6 to $8 \mathrm{~min}$, and stability (S) above $7.5 \mathrm{~min}$.

Farinograph analysis is directly related to the gluten-forming proteins of the wheat flour, which absorb water and develop a protein network capable to resist to the mixing process. The replacement of the wheat flour by gluten-free cereal and/or tuber flours leads to dilution of the gluten complex, resulting in a weakening of the dough. The increasing replacement of WF by SPF significantly increased water absorption (WA), probably due to the greater swelling power of tuber starches (Collado and Corke 1997) and partial starch gelatinization of the SPF during blanching of the sweet potatoes.

With respect to the alveograph analysis, a significant increase in $\mathrm{P}$ and decrease in $\mathrm{L}$ values was observed for F2 and F3, respectively; as well as higher values of $\mathrm{P} / \mathrm{L}$. Although the ideal values of $\mathrm{P} / \mathrm{L}$ are between 0.5 and 1.20 for the production of breads, values up to 2.50 (as those found in this study) have also been found by other authors in commercial re-milled semolina currently used for bread making (Raffo et al. 2003). However, no alveograph curve was observed for F4, probably due to a failed registration, once the high amount of SPF may have caused high resistance to extension rather 
than gluten strength. Therefore, F4 was not used for the production of breads. At high replacements of WF by SPF, the greater gluten dilution hindered the formation of a three-dimensional network, thus, it did not provide suitable extensibility and elasticity for the production of breads.

\section{EVALUATION OF SWEET BREADS}

The results of the technological evaluation of sweet breads produced with blends of WF and SPF are shown in Table IV. No significant differences were observed in specific volume (SV) when compared to the control (B0), for replacement levels up to $6 \%$ SPF, while the formulation B3 (9\% SPF) presented lower SV than B0. These results corroborate the values found in the rheological analysis, since replacement levels of wheat flour by yellow SPF higher than 9\% significantly affected rheology, resulting in lower specific volumes in breads made with these blends. Bread specific volume is also known to be negatively correlated with $\mathrm{P} / \mathrm{L}$ (Pasqualone et al. 2004), when the optimum range is surpassed.

The insertion of tuber flours in bakery products can be an economic strategy to reduce wheat imports and/or increase the added value of tubers, or as a nutritional approach, since sweet potatoes may be sources of vitamins and minerals (Greene and Bovell-Benjamin 2004, Low and Van Jaarsveld 2008).

Some studies have reported a decrease in the specific volume of breads produced with blends of wheat and tuber flours at concentrations ranging from 3 to $65 \%$ (Greene and Bovell-Benjamin 2004), with tubers peeled or not subjected to different processing conditions. This decrease in the volume of breads occurred mainly because of the weakening of the gluten network with increased addition of starch-based flours.

Water activity (aw) and moisture content of breads increased significantly with the replacement of WF by SPF (Table IV), probably due to a greater water absorption by the SPF during bread making and greater retention during storage.

Higher wheat flour substitution by SPF led to higher water absorption in the farinograph analysis (Table III), and consequently to a greater amount of water necessary to produce the breads (Table I). This fact can be explained by partial starch gelatinization of SPF during the blanching step.

During storage, a decrease in aw and moisture content was observed up to day $5(p \leq 0.05)$ for all breads, with no changes from day 5 to day 9 . Although the amount of water added was different among breads, all samples lost approximately 13\% moisture throughout shelf life, which can represent economic and sensory advantages of the breads with higher moisture. Moisture loss is associated to starch retrogradation, water migration from the crumb to the crust, and from the product to the atmosphere due to the water vapor permeability of the packaging material (Cauvain 2003). The moisture gain or loss from one region to another will continuously occur to reach a dynamic equilibrium between the components and the environment (Labuza and Hyman 1998). Probably up to day 5, the balance was achieved through water migration from the crumb to the crust, and between the air and the breads in the package (Purhagen et al. 2012). The addition of SPF presented beneficial effects by increasing moisture and aw of the breads, evidencing its contribution to product freshness even after prolonged storage.

Water has a lubrication role during chewing, thus, the moisture content may affect the perception of quality of both the fresh and stored product. Within limits (established by microbiological growth), the higher the moisture content, the greater the consumers' perception of freshness is (Cauvain 2003). Therefore, the use of moistureretaining agents, such as SPF, may have a positive effect on bakery products such as cakes and pan breads by extending sensory shelf life. 
TABLE IV

Technological parameters of breads with replacement of WF by SPF during storage a .

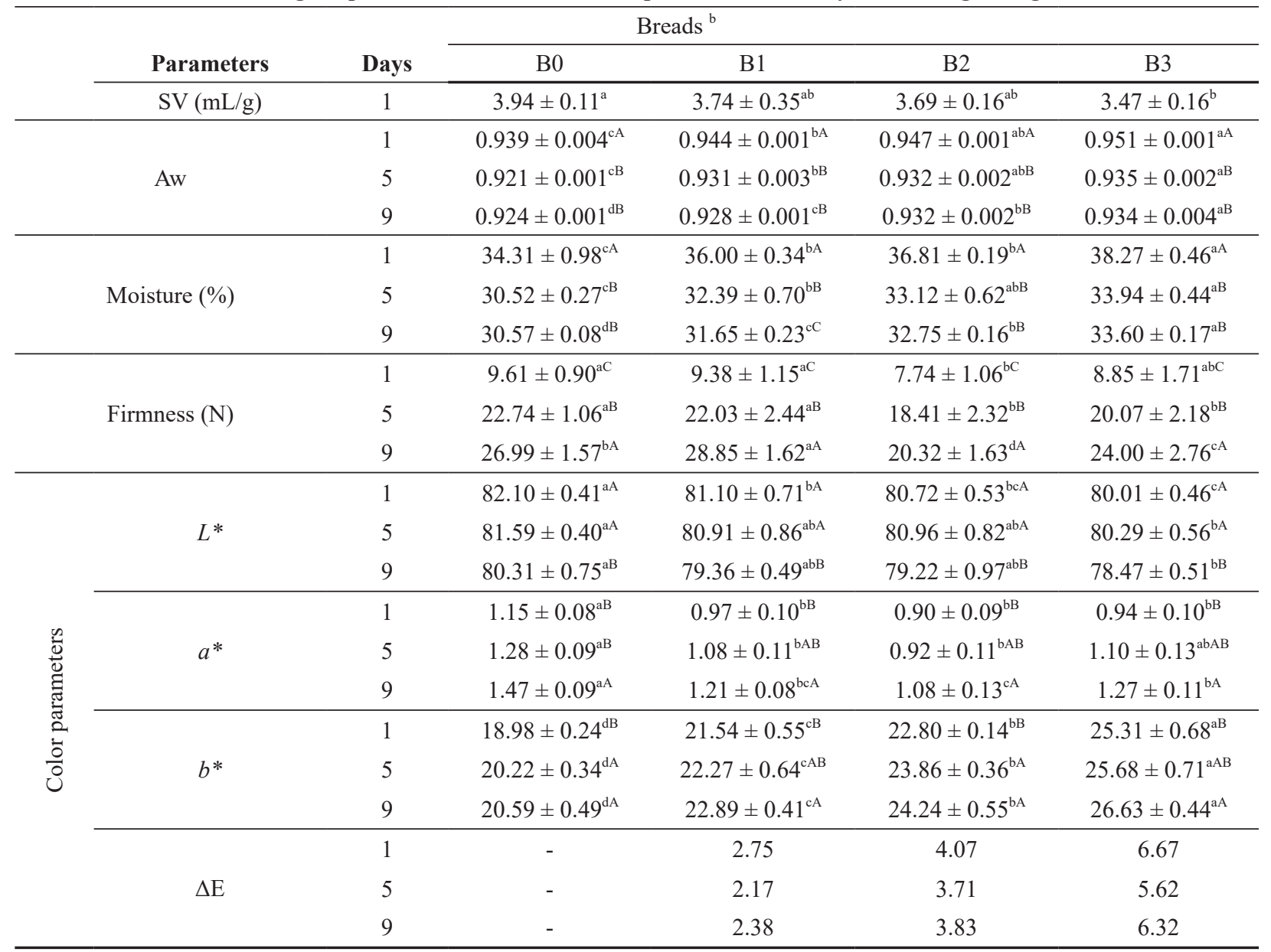

${ }^{\mathrm{a}} \mathrm{WF}=$ refined wheat flour; SPF $=$ yellow sweet potato flour; B0 = 0\% of SPF; B1 = 3\% of SPF; B2 = 6\% of SPF; B3 = 9\% of SPF; $\mathrm{SV}=$ specific volume. ${ }^{\mathrm{b}}$ Mean \pm standard deviation. $\mathrm{Aw}=$ water activity. Means with the different lowercase letters in the same line and different capital letters in the column for the same parameter differ statistically $(p \leq 0.05)$ by Tukey's test.

On the first day of storage, a significant decrease in firmness of the breads with the increase of SPF was observed, which indicates that the SPF was suitable for production of softer breads. During 9 days of storage, a progressive increase in firmness was observed in all breads, with lower firmness values for the formulation B2 (Table IV). In general, the formulations $\mathrm{B} 0$ and $\mathrm{B} 1$ had the greatest firmness, with no significant differences between them (except on day 9). The lowest firmness observed in the formulations B2 and B3 may be due to their higher moisture content, which has a positive effect on texture.
The color of the crumb was also determined due to the higher levels of carotenoids, anthocyanins, and phenolic compounds in SPF, which can undergo chemical transformations during mixing, proofing, and baking steps. In general, the breads with SPF presented a yellowish crumb, which increased with the addition of SPF.

On day 1, all formulations containing SPF showed significantly lower $L^{*}$ values when compared to the control. On day 9, a significant decrease in lightness was observed for the formulations B0 and B3. The control bread (B0) presented higher $a^{*}$ values than the breads with 
SPF (B1 and B3), which did not differ amongst themselves. The $a^{*}$ values were constant up to day 5 , and significantly increased on day 9 . For the parameter $b^{*}$, a significant increase with greater replacements of WF by SPF was observed on day 3 . Higher $b^{*}$ values were observed for the breads B0 and B2 up to day 5, while B1 and B3 exhibited higher $b^{*}$ values only on day 9 .

The present results corroborate the findings of Amenya and Wilson (1997), who found a positive correlation between $b^{*}$ values (yellow) and $\beta$-carotene levels in sweet potatoes. With respect to the $a^{*}$ values, a decrease was observed with the increase in replacement of wheat flour by yellow SPF, which was not observed by Takahata et al. (1993), who reported a correlation between $a^{*}$ values and $\beta$-carotene levels.

For $\Delta \mathrm{E}$, according to Francis and Clydesdale (1975), values close to zero indicate that the formulations presented characteristics similar to the control, while differences greater than or equal to 2 can evidence a difference between both treatments, noticeably visible to the human eye. The increase in replacements of WF by SPF led to higher $\Delta \mathrm{E}$ values (Fig. 1). Although during storage, lower $\Delta \mathrm{E}$ values were observed in breads with SPF, this difference was not detected by the human eye.

\section{CONTENT OF $\beta$-CAROTENE}

Table V presents the $\beta$-carotene levels in breads made with SPF and their stability during 9 days of storage.

The $\beta$-carotene losses during bread making (calculated by the difference between the $\beta$-carotene in SPF and in breads) were $8.33 \%, 25.02 \%$, and $13.04 \%$ for B1, B2, and B3, respectively. These losses are due to the low stability of this compound to light, oxygen, and temperature (Fonseca et al. 2008), considering it was subjected to drastic conditions such as mixing, proofing, and baking

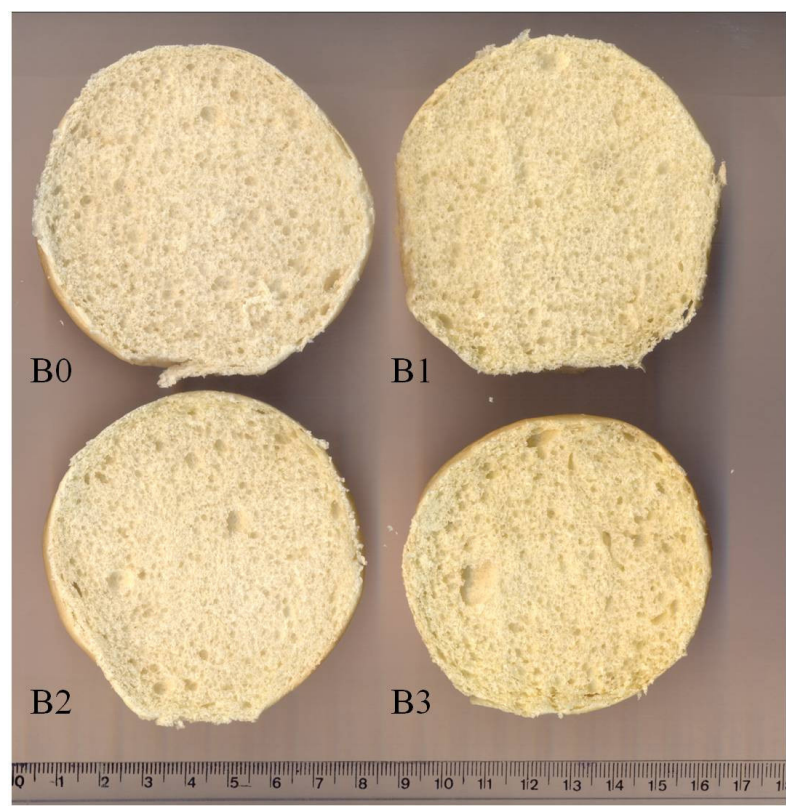

Figure 1 - Breads produced with sweet potato flour (SPF). B0 $=0 \%$ of SPF $; \mathrm{B} 1=3 \%$ of SPF; B $2=6 \%$ of SPF; B $=9 \%$ of SPF.

steps, gluten oxidation reactions, microorganism metabolism reactions, and high temperatures.

As expected, $\beta$-carotene was not detected in control breads (B0), while an increase of this compound was observed in breads with SPF, which increased significantly from B1 to B3. The contribution of $\beta$-carotene (day 1 ) per serving (1 unit) was 7.45, 12.20, and $21.21 \mu \mathrm{g} / 45 \mathrm{~g}$ for B1, B2, and B3, respectively. These values correspond to $0.27,0.45$, and $0.79 \%$ of the daily intake recommendations of $\beta$-carotene for children aged 4 to 6 years. These results indicate that the replacement of WF by SPF in bakery products may help to increase $\beta$-carotene intake (provitamin A) for children. Furthermore, the SPF, due to its content of reduced sugars, can also be used to replace sucrose added.

During storage, no changes were observed for the $\beta$-carotene levels in formulation B1, while higher values were observed in B2 on day 9, and lower values in B3 on day 5 . This variation can be due to the higher moisture content during storage and changes in the packaging and storage 
TABLE V

$\beta$-carotene $(\mu \mathrm{g} / \mathrm{g})$ in breads made with sweet potato flour during storage*

\begin{tabular}{cccc}
\hline & $1^{\text {st }}$ DAY & $5^{\text {th }}$ DAY & $9^{\text {th }}$ DAY \\
\hline B0 & nd & nd & nd \\
B1 & $0.1656 \pm 0.0081^{\mathrm{c}, \mathrm{NS}}$ & $0.1628 \pm 0.0088^{\mathrm{c}, \mathrm{NS}}$ & $0.1778 \pm 0.0093^{\mathrm{c}, \mathrm{NS}}$ \\
B2 & $0.2710 \pm 0.127^{\mathrm{b}, \mathrm{B}}$ & $0.2294 \pm 0.0041^{\mathrm{b}, \mathrm{B}}$ & $0.3281 \pm 0.0260^{\mathrm{b}, \mathrm{A}}$ \\
B3 & $0.4715 \pm 0.0341^{\mathrm{a}, \mathrm{A}}$ & $0.3685 \pm 0.0279^{\mathrm{a}, \mathrm{B}}$ & $0.3754 \pm 0.0084^{\mathrm{a}, \mathrm{B}}$ \\
\hline
\end{tabular}

*Mean \pm standard deviation. B $0=0 \%$ of SPF; B1 $=3 \%$ of SPF; B2 $=6 \%$ of SPF; B $3=9 \%$ of SPF. Means with the different lowercase letters in the same column and different capital letters for the same line differ statistically $(p \leq 0.05)$ by Tukey test; nd = below the limit of detection; $\mathrm{NS}=$ not significant $(p \leq 0.05)$. The values are in dry matter.

system, which might have changed the content of carotenoids in these products. Commercial packaging was used, which allows gas and water vapor exchanges. Therefore, further studies on packaging systems are required to preserve the bioactive compounds and moisture levels in breads, since different packaging materials and packaging systems for SPF are crucial for the preservation of the carotenoid content (Alves et al. 2012).

This study has shown a technological and nutritional viability for using tubers in higher value-added products, such as breads. Once great losses occur in yellow sweet potato crops due to lack of post-harvest processing, this study can economically contribute with crops grown in different soil and climate conditions, besides allowing production by large and small farmers (Bovell-Benjamin 2007).

\section{CONCLUSIONS}

The processing of yellow sweet potato into flour increased its added value, and may be a promising alternative as food dye and source of $\beta$-carotene in breads, which can generate economic gains for agribusiness and nutritional benefits for individuals with vitamin A deficiency.

The production of sweet breads was viable up to $9 \%$ replacement of WF by SPF because there were no changes in the technological characteristics of specific volume and firmness.
The yellow sweet potato flour contributed to increase the level of $\beta$-carotene in sweet bread, which was maintained during the storage period, and the yellowish color of the crumb, conferring an advantage, because yellow sweet potato acted as natural dye.

\section{ACKNOWLEDGMENTS}

The authors are grateful to Conselho Nacional de Desenvolvimento Científico e Tecnológico (CNPq), Fundação de Amparo à Pesquisa do Estado de São Paulo (FAPESP) and Moinho Paulista (SP, Brazil).

\section{REFERENCES}

AACC - AMERICAN ASSOCIATION CEREAL CHEMISTRY INTERNATIONAL. 2010. Approved Methods of Analysis, $11^{\text {th }}$, St. Paul.

ABITRIGO - ASSOCIAÇÃO BRASILEIRA DA INDÚSTRIA DO TRIGO. 2016. Disponível em: http://www.abitrigo. com.br/pdf/mdic/importacao_trigo.pdf. Acesso em 29 de Março de 2016.

ALI N, FALADE OK AND AKINGBALA JO. 2012. Effect of cultivar on quality attributes of sweet potato fries and crisps. Food Nutr Sci 3: 224-232.

ALVES RMV, ITO D, CARVALHO JLV, MELO WF AND GODOY RLO. 2012. Stability of biofortified sweet potato flour. Braz J Food Technol 15: 59-71.

AMENYA AM AND WILSON PW. 1997. Relationship between hunter color values and $\beta$-carotene contents in white-fleshed African sweet potatoes (Ipomoea batatas Lam.). J Sci Food Agric 73: 301-306.

BOVELL-BENJAMIN AC. 2007. Sweet potato: a review of its past, present, and future role in human nutrition. Adv Food Nutr Res 52: 1-59.

BRASIL. 2001. Ministério da Agricultura, Pecuária e do Abastecimento. Instrução Normativa $n^{\circ} 7$, de 15 de agosto 
de 2001. Regulamento técnico de identidade e de qualidade do trigo. Brasília: MAPA.

BRASIL. 2005a. Ministério da Agricultura, Pecuária e do Abastecimento. Instrução Normativa $n^{\circ} 8$, de 2 de junho de 2005. Regulamento técnico de identidade e qualidade da farinha de trigo. Brasília: MAPA.

BRASIL. 2005b. Agência Nacional de Vigilância Sanitária. RDC n ${ }^{\circ} 263$, de 22 de setembro de 2005. Regulamento técnico para produtos de cereais, amidos, farinhas e farelos. Brasília, ANVISA.

CAUVAIN SP. 2003. Breadmaking: improving quality, $2^{\text {nd }} e d$., Cambridge: Woodhead Publishing Limited, 608 p.

COLLADO LS AND CORKE H. 1997. Properties of starch noodles as affected by sweet potato genotype. Cereal Chem 74: 182-187.

DANZER K AND CURRIE LA. 1998. Guidelines for calibration in analytical chemistry. Pure and App Chem 70: 993-1014.

DONADO-PESTANA CM, SALGADO JM, RIOS AO, SANTOS PR AND JABLONSKI A. 2012. Stability of carotenoids, total phenolics and in vitro antioxidant capacity in the thermal processing of orangefleshed sweet potato (Ipomoea batatas Lam.) cultivars grown in Brazil. Plant Foods Hum Nutr 67: 262-270.

FONSECA MJO, SOARES AG, FREIRE JUNIOR M, ALMEIDA DJ AND ASCHERI JLR. 2008. Effect of extrusion-cooking in total carotenoids content in cream and orange flesh sweet potato cultivars. Hortic Bras 26: 112-115.

FRANCIS JF AND CLYDESDALE FM. 1975. Food colorimetry, theory and applications. New York: Van Nostrand Reinhold/AVI, $477 \mathrm{p}$.

GREENE JL AND BOVELL-BENJAMIN AC. 2004. Macroscopic and sensory evaluation of bread supplemented with sweet-potato flour. J Food Sci: Sensory and Nutritive Qualities of Food 69: 167-173.

INSTITUTO ADOLFO LUTZ. 2008. Métodos físicoquímicos para análise de alimentos. São Paulo: Instituto Adolfo Lutz. Disponível em: http://www.ial.sp.gov.br/ index.php? option $=$ com_remository \&Itemid $=20$. Acesso em 31 de Outubro de 2015.
LABUZA TP AND HYMAN CR. 1998. Moisture migration and control in multi-domain foods. Trends Food Sci Technol 9: 47-55.

LOW JW AND VAN JAARSVELD PJ. 2008. The potential contribution of bread buns fortified with $\beta$-carotene-rich sweet potato in Central Mozambique. Food Nutr Bul 29: 98-107.

MINOLTA K. 1993. Precise color communication: color control form feeling to instrumentation. Osaka: Minolta Camera Co. Ltd., 49 p.

PASQUALONE A, CAPONIO F AND SIMEONE R. 2004. Quality evaluation of re-milled durum wheat semolinas used for bread-making in Southern Italy. Eur Food Res Technol 219: 630-634.

POMERANZ Y. 1988. Wheat, Chemistry and Technology, $3^{\text {rd }}$ ed., Saint Paul: American Association of Cereal Chemists.

PURHAGEN JK, SJÖÖ ME AND ELIASSON AC. 2012. Fibre-rich additives - the effect on staling and their function in free-standing and pan-baked bread. J Sci Food Agric 92: 1201-1213.

RAFFO A, PASQUALONE A, SINESIO F, PAOLETTI F, QUAGLIA G AND SIMEONE R. 2003. Influence of durum wheat cultivar on the sensory profile and staling rate of Altamura bread. Eur Food Res Technol 218: 49-55.

RODRIGUEZ-AMAYA DB. 2001. A Guide to Carotenoid Analysis on Food. Washington: ILSI Press.

RODRIGUEZ-AMAYA DB AND KIMURA M. 2004. HarvestPlus handbook for carotenoid analysis. Washington: HarvestPlus, $58 \mathrm{p}$.

RODRIGUEZ-AMAYA DB, NUTTI MR AND CARVALHO JL V. 2011. Carotenoids of sweet potato, cassava, and maize and their use in bread and flour fortification. In: Preedy VR, Watson RR and Patel VB (Eds), Flour and breads and their fortification in health and disease prevention. London: Academic Press, p. 301-311.

SCHILLER GW. 1984. Bakery flour specifications. Cereal Food World 29: 647-651.

TAKAHATA Y, NODA T AND NAGATA T. 1993. HPLC determination of $\beta$-carotene of sweet potato cultivars and its relationship with color values. Jpn J Breed 43: 421-427. 